\title{
Penerapan Metode Proyek Dalam Mengembangkan Sosial Anak Usia 5-6 Tahun
}

\author{
Bujuna Alhadad ${ }^{1}$, Umikalsum Arfa ${ }^{2}$, Hanisa Sulman ${ }^{3}$ \\ Universitas Khairun Ternate \\ Fakultas Keguruan dan Ilmu Pendidikan \\ Jl. Bandara Sultan Baabullah Kota Ternate Utara, Kotak Pos 53 Ternate 977328 \\ Telepon: (0921) 3110905-Faksimili 0921-3110901 \\ Email: bujunaalhadad@gmail.com
}

\begin{abstract}
Abstrak: Dalam kajian ini penulis menggunakan kajian literatur, yaitu serangkaian kegiatan yang berkenaan dengan metode pengumpulan data pustaka.Kajian ini bertujuan (1) mendeskrpisikan bagaimana mengembangkan aspek sosial anak usia 5-6 tahun dengan menggunakan metode proyek, (2) mendeskripsikan faktor-faktor yang berpengaruh dalam mengembangkan aspek sosial anak usia dini melalui metode proyek, (3) mendeskripsikan cara mengembangkan aspek sosial anak usia dini melalui metode proyek. Hal tersebut sangat penting karena kemampuan sosial tidak dimiliki oleh anak usia dini secara alami, tetapi harus ditumbuhkan dan dikembangkan oleh orang tua maupun pendidik PAUD dengan mengambangkan aspek sosial anak usia dini melalui metode proyek.Metode proyek merupakan metode pembelajaran aktif dimana anak diberi kebebasan dalam memilih kegiatan bahan ajarnya diorganisasikan sedemikian rupa, serta mengandung suatu pokok masalah dan memberikan kesempatan pada anak-anak bersosialisasi dan bekerja sama dengan kelompoknya. Sehingga dalam penelitian ini metode proyek dipandang dapat diterapkan dalam mengembangkan kemampuan bersosialisasi anak usia 5-6 tahun di Taman Kanak-kanak. Kemampuan sosial harus ditanamkan sejak dini agar anak lebih mudah berinteraksi atau berhubungan dengan lingkungannya. Dalam bersosialisasi anak akan mudah diterima karena anak memiliki kemampuan sosial yang baik seperti mudah bergaul, berbagi dengan teman, bertanggung jawab atas perbuatannya, menghargai temannya. Interaksi sosial pada anak pertama kali terjadi dalam lingkungan keluarga terutama orang tua dan saudara.
\end{abstract}

Kata kunci: Metode Proyek, Perkembangan Sosial Anak.

\begin{abstract}
The writer used library research, which is a series of activities relating to the method of collecting library data. This study aimed (1) to describe how to develop the social aspects of children aged 5-6 years using the project method, (2) describe the factors that influence in developing social aspect of early childhood through the project method, (3) describe how to develop social aspects of early childhood through the project method. This is very important because social abillity are not passed by early childhood naturally, but must be grown and developed by parents and teachers by developing the social aspect of early childhood using the project method. The project method is an active learning method where children can choose the activities, the teaching materials, organized in such a way, and contain a problem and provide opportunities for children to socialize and cooperate with their groups to solve the problem. So that in this study the project method is seen to be applied in developing the social ability of children aged 5-6 years in kindergarten. Social ability must be instilled early, so that children more easily interact to their environment.In socializing children will be easily accepted because children have good social skills such as easy to get along, share with friends, take responsibility for their actions, respect their friends. Social interaction in children first occurs in the family environment, especially parents and relatives.
\end{abstract}

Keywords: the project method, Child Social Development.

\section{A. Pendahuluan}

Seluruh aspek perkembangan anak tersebut dapat di kembangkan melalui program pendidikan anak usia dini, pendidikan anak usia dini merupakan upaya yang dilakukan untuk memberikan stimulasi pertumbuhan dan perkembangan pada anak pada masa ini anak tidak dibina secara tepat maka anak akan mengalami gangguan perkembangan emosi, mental, sosial, intelektual dan moral yang akan menentukan sikap serta perilaku sosial seseorang ketika dewasa. Salah satu aspek perkembangan anak yang dapat di kembangkan 
sebagai bekal kehidupan sekarang dan masa yang akan datang adalah aspek perkembangan sosial karena manusia merupakan mahluk sosial yang tidak biasa hidup tanpa adanya interaksi dengan manusia lain.Perkembangan sosial anak bermula dari semenjak bayi, sejalan dengan pertumbuhan badanya, bayi yang telah menjadi anak dan seterusnya menjadi orang dewasa itu, akan mengenal lingkungannya yang lebih luas, mengenai banyak manusia, perkenalan dengan orang lain di mulai dengan mengenal ibunya, kemudian mengenal ayah dan keluarganya. Selanjutya manusia yang dikenalnya semakin banyak dan amat hitrogen akan bisa menyesuaikan diri untuk masyarakat lebih luas. Akhirnya manusia mengenal kehidupan bersama, kemudian bermasyarakat atau bernegara dalam berkehidupan sosial. Dalam pekembangan anak (manusia) akhirnya mengetahui bahwa manusia itu saling bantu membantu, dan saling memberi dan menerima.

Menurut peraturan Mentri Pendidikan Nasional Nomor 137 tahun 2013 tingkat pencapaian perkembangan sosial anak usia 5-6 tahun meliputi:

1. Bermain dengan teman sebaya

2. Berbagi dengan orang lain

3. Menghargai hak/pendapat/karya orang lain

4. Bersifat komperatif

5. Menunjukan sikap toleran

6. Mengenal tata karama dan sopan santun sesuai dengan nilai sosial budaya setempat.

Perkembangan sosial anak perlu di kembangkan sejak usia dini karena memiliki dampak terhadap kesiapan anak memasukii dunia sekolah adalah anak yang mampu menjalin pertemanan, mempertahankan pertemanan, dan dapat berkomunikasi dengan baik terhadap teman maupun gurunya. Alasan lain mengenai pentingnya mengembangkan perkembngan sosial anak sejak dini yaitu dikarenakan perilaku sosial tersebut akan terbawa hingga dewasa. Jadi jika tidak dibina secara tepat sejak usia dini akan berdampak pada kemampuanya bersosialisasi ketiak dewasa.

Kemampuan sosial anak merupakan kemampuan anak dalam berinteraksi atau berhubungan dengan lingkungannya, sehingga anak dapat diterima dalam lingkungannya. Lingkungan akan mudah menerima anak yang memiliki kemampuan sosial yang baik seperti mudah bergaul, berbagi dengan teman, bertanggung jawab atas perbuatannya, menghargai temannya. Interaksi sosial pada anak pertama kali terjadi dalam lingkungan keluarga terutama orang tua dan saudara. Peran orang tua sangat penting dalam menanamkan keterampilan sosial.

Ada berbagai macam metode yang dapat meningkatkan perkembangan sosial anak salah satunya melalui penggunaan metode proyek. Metode proyek adalah sebuah metode yang memberikan pengalaman belajar melalui pemberian sebuah kegiatan yang harus di kerjakan secara kelompok untuk mencapai tujuan bersama, sehingga dalam kelompok tersebut akan muncul proses berinteraksi,bersosialisasi, dan kerjasama antara anak yang satu dengan anak yang lain. Dalam berkelompok salah satu anak menjadi pemimpin kelompok agar dapat sejalan dengan apa yang di inginkan untuk mencapai tujuan bersama. Guru memberikan tugas proyek yang dikerjakan oleh anak-anak kemudian mendiskusikan dengan teman-temannya, berbagi tugas satu sama lain. Metode proyek dapat Meningkatkan keterampilan sosial anak melalui diskusi kelompok dengan begitu anak akan berinteraksi satu sama lain. Diskusi merupakan cara yang tepat untuk meningkatkan keterampilan sosial anak.

Menurut (Moeslichatoen, 2004) "Metode proyek merupakan salah satu cara pemberian pengalaman belajar dengan menghadapkan anak dengan persoalan sehari-hari yang harus dipecahkan secara berkelompok". Metode proyek merupakan strategi pengajaran yang melibatkan anak dalam belajar memecahkan masalah dengan melakukan 
kerjasama dengan anak lain, masing-masing melakukan bagian pekerjaannya secara individual atau dalam kelompok kecil untuk mencapai tujuan yang menjadi milik bersama.Gagasan ini dikembangkan oleh William H. Kilpatrich dalam metode proyek. Metode proyek merupakan "Salah satu cara pemecahan masalah yang diterapkan secara luas daalm setiap pemecahan masalah yang dialami dalam kehidupan sehari-hari" (Bossing, Moeslichatoen 2004).

Menurut (Rooprine dan Jhonson, 2011) "metode proyek memberikan konteks yang sering dan nyata dimana anak-anak dibantu dalam mengembangkan berbagai macam pengetahuan sosial, keterampilan sosial, pembwaan dan perasaan sosial pada sifat antar pribadi”. Berdasarkan pendapat tersebut dapat di artikan bahwa metode proyek menjadi sala satuh cara untuk memecahkan masaalah terkait perkembangan sosial anak keunggulan metode proyek ini diantranya anak terlibat dalam suatu kegiatan bersama yang memacu anak untuk berinteraksi dengan temanya sehingga berpengaruh terhadap perkembangan sosialnya penggunaan metode proyek ini dapat membiasakan anak berinteraksi dengan sesamanya. Oleh sebab itu penggunaan metode proyek diharapkan dapat meningkatkan perkembangan sosial anak.

Metode proyek menjadi penting untuk diterapkan pada anak usia dini karena berkaitan dengan kehidupan sehari-hari secara nyata sehingga anak belajar dari pengalamannya sendiri. Hal ini terbukti lebih bermakna dibandingkan metode biasa. Selain itu anak dapat belajar mengatur diri sendiri untuk bekerja sama dengan teman dalam memmecahkan masalah dan dapat berdampak dalam pengembangan etos kerja.

(Agustiana, 2017) menyatakan bahwa "metode proyek merupakan salah satu cara pemberian pengalaman belajar kepada anak. Anak langsung dihadapkan pada persoalan sehari-hari yang menuntut anak untuk melakukan berbagai aktivitas sesuai proyek yang diberikan". Keunggulan dari metode proyek ini diantaranya anak terlibat dalam suatu kegiatan bersama yang memacu anak dengan masalah sosial dan anak dapat berinteraksi dengan temannya sehingga perkembangan sosial anak tersebut dapat meningkat. Penerapan metode proyek ini diasumsikan dapat membiasakan anak untuk berinteraksi dengan sesamanya, serta membiasakan anak untuk memilih, merancang dan memimpin pekerjaan dalam mencapai tujuan bersama.

(Roopnarine dan Johnson, 2011) juga mengungkapkan bahwa metode proyek merupakan strategi pengajaran yang melibatkan anak dalam belajar memecahkan masalah dengan melakukan kerja sama dengan anak lain baik secara individu maupun kelompok dalam melaksanakan pekerjaan dengan topik tertentu.

Penelitian yang dilakukan oleh (Astuti dkk, 2013) "metode proyek adalah suatu metode untuk melatih anak dalam memecahkan masalah yang dialami anak dalam kehidupan sehari-hari”. Cara ini juga dapat menggerakkan anak untuk melakukan kerja sama sepenuh hati. Kerja sama di laksanakan secara terpadu untuk mencapai tujuan bersama. Metode proyek dapat meningkatkan kemampuan sosial anak karena kegiatan dalam metode proyek mengutamakan kerjasama tim dalam menyelesaikan tugas.

Pada dasarnya pembelajaran harus bisa terwujud dalam suasana yang menyenangkan serta melibatkan keaktifan peserta didik, agar peserta didik mendapatkan pembelajran yang bermakna dan benar-benar memahami apa yang sudah dipelajari. Pembelajaran tersebut dapat dilaksanakan dengan salah satu metode yaitu metode proyek. Penelitian yang dilakukan oleh (Rahayu, 2013) menyatakan bahwa dengan metode proyek anak dapat melatih diri untuk mandiri dan percaya diri, menghargai teman, membangun sikap positif terhadap lingkungan dan bekerja bersama, serta melatih anak menerima tanggung jawab. Menurut (Alfiana, 2015) "Proyek berasal dari kata bahasa latin royectycum yang memiliki makna maksud, tujuan dan rencana". Pada pembelajaran proyek anak- anak dilibatkan 
dalam memilih topik pembelajaran yang menarik dan ingin di ketahui lebih dalam dapat dilakukan secara individu maupun kelompok. Pengetahuan yang di dapat dari hasil melakukan sendiri, membuat anak mampu mengingat pengalaman tersebut, membangun pemahaman yang lebih mendalam, menumbuhkan rasa ingin tahu, dan mendapat penghargaan tersendiri bagi anak. Metode proyek adalah suatu jenis kegiatan memecahkan masalah yang dilakukan oleh perseorangan atau kelompok kecil. Metode proyek biasanya dilakukan oleh anak dalam satu kelas, dan hasilnya akan lebih baik jika dilakukan secara berkelompok.

Berdasarkan uraian di atas, jelaslah bahwa metode proyek merupakan metode pembelajaran aktif dimana anak diberi kebebasan dalam memilih kegiatan, sehingga dapat disimpulkann bahwa metode proyek itu suatu metode mengajar yang bahan ajarnya diorganisasikan sedemikian rupa, serta mengandung suatu pokok masalah dan memberikan kesempatan pada anak-anak untuk bersosialisasi dan bekerja sama dengan kelompoknya yang harus dipecahkan baik secara individu maupun berkelompok, sehingga metode proyek dalam penelitian ini dipandang dapat diterapkan dalam Smengembangkan kemampuan bersosialisasi anak usia 5-6 tahun di Taman Kanak-kanak.

(Yusuf dan Sugandhi, 2016) menyatakan bahwa "perkembangan sosial merupakan pencapaian kematangan dalam hubungan atau interaksi sosial". Maka dapat juga diartikan sebagai proses belajar untuk menyesuaikan diri dengan norma-norma kelompok, tradisi, dan moral agama. Perkembangan sosial juga dapat dipandang sebagai perolehan kemampuan berperilaku yang sesuai dengan tuntutan sosial. Seorang anak akan dianggap berhasil dalam kehidupannya bukan karena nilai yang baik disekolahnya, melainkan anak yang mempunyai kemampuan sosial yang baik, akan membuat anak dengan mudah menyesuaikan diri dengan baik terhadap lingkungan hidupnya dapat menikmati masa kecilnya dan mampu menjadi orang dewasa dengan kemampuan adaptasi dengan baik. Anak usia dini harus dilatihkan untuk berani mengungkapkan yang di rasakan dan di pikirkan, sehingga pada nantinya anak dapat bekerjasama, dengan teman, mudah mengungkapkan pendapat di depan banyak orang dan mudah berinteraksi.

Penelitian lain dilakukan oleh (Lestari, 2016) menyatakan bahwa perekembangan sosial khususnya dalam hal kemampuan kerjasama belum optimal, dilihat dari perilaku anak masih belum dapat bekerja dalam kelompok, masih enggan bermain bersama-sama, serta masih belum dapat menunjukkan sikap peduli terhadap teman. Beberapa anak juga masih sulit untuk berbagi mainan serta cenderung sering berebut. Saling menyerang dan berkelahi juga kerap kali terjadi pada saat kegiatan di dalam kelas. melihat hal ini perlunya dilakukan upaya penerapan pebelajaran yang inovatif dalam meningkatkan kemampuan sosioemosional. Penelitian Penelitian yang dilakukan oleh (Widyaningrum, 2016) terdapat anak yang suka menyendiri, pendiam, tidak pandai berkomunikasi dengan orang lain. Anak yang memiliki sikap seperti itu akan sulit diterima oleh kelompok dan sulit untuk diajak bekerja sama. Kegiatan pembelajaran dikelompok B masih didominasi individual, hal tersebut terlihat dari pembelajaran yang dominan menggunakan lembar kerja anak (LKA), dan menekankan pada kemampuan kognitif seperti baca tulis hitung permulaan. Berdasarkan hasil observasi dan wawancara guru kelas yang dilaksanakan pada hari Rabu, 3 Januari 2018 di kelompok B TK Gugus III Kecamatan Tampaksiring ditemukan permasalahan perkembangan sosial anak yang muncul dalam proses pembelajaran yaitu anak belum mampu menyesuaikan diri dengan orang lain, masih banyak anak-anak yang pasif di dalam kegiatan proses pembelajaran. Saat proses pembelajaran di kelas diperoleh data anak yang berkembang sesuai harapan bisa dikatakan dapat menyelesaikan kegiatan dengan mandiri, dan ada pula anak yang mulai berkembang, sedangkan ada anak yang belum mau bersosialisasi dengan temannya. Hal ini dikarenakan anak masih sulit untuk beradaptasi dengan lingkungan barunya. Kondisi seperti ini bisa terjadi pada anak dari latar 
belakang dimana mereka jadi anak tunggal sehingga orang tuanya selalu menajakan dan apa kemuan sang anak selalu dituruti oleh orang tuanya.

Berdasarkan penelitian sebelumnya betapa pentingnya kemampuan sosial untuk anak. Kemampuan sosial harus ditanamkan sejak dini agar anak lebih mudah berinteraksi atau berhubungan dengan lingkungannya, sehingga anak dapat diterima dalam lingkungannya. Lingkungan akan mudah menerima anak yang memiliki kemampuan sosial yang baik seperti mudah bergaul, berbagi dengan teman, bertanggungjawab atas perbuatannya, menghargai temannya. Interaksi sosial pada anak pertama kali terjadi dalam lingkungan keluarga terutama orang tua dan saudara.

\section{B. Pembahasan}

\section{Defenisi Metode Proyek}

Metode pembelajaran proyek memperoleh respon positif dari anak-anak ketika proses pembelajaran berlangsung. Ketika pembelajaran dengan metode proyek berlangsung, anak tidak lagi pasif sebagai pendengar saja. Anak menjadi aktif, mampu bekerjasama dan bersemangat dalam mengikuti kegiatan pembelajaran. Hal ini sesuai teori yang di kemukakan oleh (Yus,2011) meyatakan bahwa pembelajaran dengan menggunakan metode proyek merupakan sala satu cara pemberian pengalaman belajar kepada anak. Anak langsung dihadapkan pada persoalan sehari-hari yang menuntut anak untuk melakukan berbagai aktifitas sesuai dengan proyek yang diberikan. Dari aktifitas tersebut anak memperoleh pengalaman yang akan membentuk perilaku sebagai suatu kemampuan yang di miliki. Berbeda dengan kelompok control, kegiatan pembelajaran konvensional yang hanya menggunakan metode ceramah lebih bersifat menonton, guru lebih banyak berbicara, dimana peran seorang guru disini adalah meyiapkan informasi kepada peserta didik, sedangkan peranan peserta didik adalah menerima, meyimpan, dan melakukan aktifitas-aktifitas yang sesuai dengan informasi yang diberikan, pembelajaran yang kurang inovatif dan kurangnya memanfaatkan media pembelajaran dalam proses pembelajaran.

Metode proyek menurut (Djamarah dan Aswan Zain, 2014) Metode proyek atau unit merupakan cara penyajian pelajaran yang bertitik tolak dalam suatu masalah, kemudian di bahas dari berbagai segi yang berhubungan sehingga dapat dipecahkan secara keseluruhan dan bermakna. Metode proyek merupakan cara yang menggunakan titik tolak yang menyajikan permasalahan bermakna yang berhubungan sehingga dapat dipecahkan. Metode proyek menurut "Buku Panduan Pendidikan kurikulum 2013 PAUD" metode proyek merupakan suatu tugas yang terdiri atas rangkaian kegiatan yang diberikan oleh pendidik kepada anak, baik secara berkelompok maupun individu dengan menggunakan objek alam sekitar maupun kegiatan sehari-hari. Metode proyek merupak an rangkaian kegiatan yang diberikan guru terhadap anak dalam bentuk berkelompok maupun individu untuk mempelajari alam sekitar dan kegiatan seharihari.

Menurut (Yus,2011) metode proyek merupakan salah satu cara pemberian pengalaman belajar kepada anak. Anak langsung dihadapkan pada peroalan sehari-hari yang menuntut anak untuk melakukan berbagai aktivitas sesuai proyek yang diberikan. Dari aktivitas tersebut anak memperoleh pengalaman yang akan membentuk perilaku sebagai suatu kemampuan yang di miliki

Menurut (Afiana, 2015) "Proyek berasal dari kata bahasa latin royectycum yang memiliki makna maksud, tujuan dan rencana". Pada pembelajaran proyek anak-anak dilibatkan dalam memilih topik pembelajaran yang menarik dan ingin di ketahui lebih dalam dapat dilakukan secara individu maupun kelompok. Pengetahuan yang di dapat dari hasil melakukan sendiri, membuat anak mampu mengingat pengalaman tersebut, 
membangun pemahaman yang lebih mendalam, menumbuhkan rasa ingin tahu, dan mendapat penghargaan sendiri bagi anak. Metode proyek adalah suatu jenis kegiatan memecahkan masalah yang dilakukan oleh perseorangan atau kelompok kecil. Metode proyek biasanya dilakukan oleh anak dalam satu kelas, dan hasilnya akan lebih baik jika dilakukan secara berkelompok. Metode proyek adalah "suatu cara mengajar yang memberikan kesempatan anak didik untuk menggunakan unit kehidupan sehari-hari sebagai bahan pelajarannya (Hamdayana,2016). Adapun tujuan dari metode proyek adalah pengetahuan selama masa prasekolah dapat mencakup sejumlah gagasan, konsep, skema, informasi, dongeng, legenda, dan nyayian, kecakapan didefinisikan sebagai suatu tindakan yang memiliki nilai tersendiri, khusus dan dengan mudah di observasi dan di ukur, seperti menggunting dan melipat kecenderungan umumnya berhubungan dengan pembiasaan yang bertahan terus menerus dalam pemikiran atau karakter cara anak merespon pengalaman yang berlangsung dalam berbagai macam situasi, seperti kemampuan dalam memecahkan masalah. Dengan demikian, metode proyek dapat membantu meningkatkan kemampuan sosial anak usia 5-6 tahun Melalui metode proyek anak dapat mengembangkan pengetahuan mampu berinteraksi dan bersosialisasi dan mampu mengenal perasaan serta mengendalikan emosi dan dapat memecahkan masalah sederhana dalam kehidupan sehari-hari.

Metode proyek adalah metode pembelajaran yang tepat untuk merangsang dan memantapkan perkembangan intelektual dan sosial anak. Salah satu kemampuan sosial anak adalah kemampuan dalam berinteraksi, salah satu pola interaksi sosial adalah kerja sama.

Penelitian ini hanya terbatas pada kemampuan sosial. Pada usia dini sangat dibutuhkan, sebab pada usia dini sangat di butuhkan, sebab dengan memiliki kemampuan sosial anak dapat lebih muda berinteraksi dengan lingkungan sekitar atau lingkungan baru. Kemampuan sosial meliputi: keterampilan komonikasi, berbagi (sharing), bekerja sama dan berpartisipasi dalam kelompok masyarakat. Pada masa kanak-kanak inilah, usia yang paling tepat untuk mengembangkan kemampuan sosial. Dengan mengembangkan kemampuan sosial sejak dini memberikan dampak terhadap pengetahuan dan mempunyai kesadaran diri yang kuat, setiap untuk berinteraksi dengan orang lain.

Pembelajaran menggunakan metode proyek terhadap kemampuan sosial anak memberikan kesempatan anak untuk dapat meningkatkan jiwa sosialnya melalui kegiatan pembelajaran yang meyenangkan dan dapat menumbuhkan rasa kerjasama antar anak. Penelitian ini diperkuat oleh penelitian yang dilakukan oleh (Agustiana,2017) yang menunjukan bahwa pembelajaran menggunakan metode proyek dapat meningkatkan perkembangan sosial anak usia dini pada anak kelompok B dan penelitian yang di lakukan oleh (Widyaningrum,2016) yang menyatakan bahwa pembelajaran menggunakan metode proyek dapat memberikan stimulasi yang efektif untuk meningkatkan keterampilan sosial anak.

Metode proyek menjadi penting untuk diterapkan pada anak usia dini karena berkaitan dengan kehidupan sehari-hari secara nyata sehingga anak belajar dari pengalamannya sendiri. Hal ini terbukti lebih bermakna dibandingkan metode biasa. Selain itu anak dapat belajar mengatur diri sendiri untuk bekerja sama dengan temandalam memmecahkan masalah dan dapat berdampak dalam pengembangan etos kerja. Berdasarkan uraian di atas, jelaslah bahwa metode proyek merupakan metode pembelajaran aktif dimana anak diberi kebebasan dalam memilih kegiatan, sehingga dapat disimpulkann bahwa metode proyek itu suatu metode mengajar yang bahan ajarnya diorganisasikan sedemikian rupa, serta mengandung suatu pokok masalah dan memberikan kesempatan pada anak-anak untuk bersosialisasi dan bekerja sama dengan 
kelompoknya yang harus dipecahkan baik secara individu maupun berkelompok, sehingga metode proyek dalam penelitian ini dipandang dapat diterapkan dalam mengembangkan kemampuan bersosialisasi anak usia 5-6 tahun di Taman Kanakkanak.

Adapun manfaat dari metode proyek menurut (Ermawati,2013) menyebutkan manfaat dari penggunaan metode proyek bagi anak usia dini sebagai berkut:

a. Memperluas wawasan anak tentang segi-segi kehidupan dalam keluarga, sekolah, dan masyarakat

b. Anak memperoleh pemahaman tentang bagaimana memecahkan masalah tertentu yang memerlukan kerjasama dengan anak lain secara terpadu

c. Anak memperoleh pengalaman belajar pengembangan sikap positif dalam kegiatan bekerja dengan anak lain

d. Mengembangkan dan membina kerja sama dan interaksi sosial di antara anak-anak yang terlibat dalam proyek

e. Memberi kesempatan anak untuk mengembangkan etos kerja pada diri anak

f. Dapat mengeksplorasi kemampuan, minat, serta kebutuhan anak

g. Melatih anak untuk menerima tanggung jawab.

Adapun kelebihan dari metode proyek yaitu, dapat meningkatkan motivasi belajar peserta didik, meningkatkan kemampuan pemecahan masalah, membuat suasana belajar menjadi menyenangkan.

Adapun langkah kegiatan dalam metode proyek yaitu, kegiatan awal, kegiatan pengembangan, dan kegiatan penutup.

Karakteristik dari metode proyek itu adalah memiliki kebebasan yang tinggi dimana anak memilih topik dan anak mencari bahan sehingga konsekuensi yang timbul adalah anak akan memiliki motivasi yang tinggi untuk menyelesaikan pekerjaan. "Metode proyek dapat digunakan dalam pembelajaran aktif karena anak bertindak sebagai subjek belajar yang memiliki kebebasan memilih dan guru lebih bersifat sebagai fasilitator dalam pembelajaran" (Masitoh, dkk 2005).

Ada tiga tahap dalam merancang kegiatan proyek bagi anak di Taman Kanakkanak yaitu: merancang persiapan yang dilakukan guru, merancang pelaksanaan kegiatan proyek bagi anak, dan merancang penilaian kegiatan proyek bagi anak (Moeslichatoen 2004).

\section{Defenisi Perkembangan Sosial}

Menurut pakar psikologis perkembangan anak, (Elizabeth Hurlock, 2007) perkembangan sosial merupakan kemampuan berperilaku yang sesuai dengan tuntutan sosial "sosialisasi adalah kemampuan bertingkah laku sesuai dengan norma nilai atau harapan sosial". Pendapat lain mengatakan bahwa perkembangan sosial adalah pencapaian kematangan dalam hubungan sosial. Perkembangan sosial dapat pula di artikan sebagai proses belajar untuk menyesuaikan diri terhadap norma-norma kelompok, moral, dan tradisi meleburkan diri menjadi satu kesatuan dan saling berkomunikasi dan kerja sama.

Menurut (Yusuf,2006) "Perkembangan sosial merupakan pencapaian kematangan dalam hubungan sosial". Perkembangan sosial dapat pula diartikan sebagai proses belajar untuk menyesuaikan diri terhadap norma-norma kelompok, moral dan tradisi: meleburkan diri menjadi satu kesatuan dan saling berkomunikasi dan kerja sama. Pada awal manusia dilahirkan belum bersifat sosial, dalam artian belum memiliki kemampuan dalam berinteraksi dengan orang lain. 
Menurut (Sunaryo,2014) perilaku sosial adalah perilaku spesifik yang diarahkan pada orang lain. Penerimaan perilaku sosial sangat tergantung pada norma-norma sosial dan diatur oleh berbagai sarana kontrol. Perilaku individu ditentukan oleh norma yang berlaku pada suatu tempat yang dijadikan sebagai pedoman atau kebiasaan bertingkah laku dalam masyarakat. Menurut Sunaryo perilaku merupakan suatu tindakan yang memiliki manfaat bagi orang lain, seperti mau berbagi, kerja sama, menolong. Sebaliknya, perilaku anti sosial mengandung efek yang tidak bermanfaat bagi individu atau orang lain, berkenaan dengan kebahagian, kesejahteraan dan lingkungan.

Adapun pekembangan sosial menurut (Susanto, 2014) merupakan pencapaian kematangan dalam hubungan sosial. Dapat juga diartikan sebagai proses belajar untuk menyesuaikan diri terhadap norma-norma kelompok, moral dan tradisi, meleburkan diri menjadi satu kesatuan dan saling berkomonikasi dan bekerja sama.

Perkembangan sosial perlu di kembangkan kepada anak sejak dini agar kelak anak dapat memiliki perilaku sosial yang baik. Menurut (Loore dalam Susanto, 2011) menjelaskan lebih lanjut bahwa sosialisasi itu merupakan suatu prose di mana individu (terutama anak) melatih kepekaan dirinya terhadap ransangan-ransangan sosial terutama tekanan-tekanan dan tuntutan kehidupan (kelompoknya), belajar dalam lingkungan sosiokulturalnya.

Menurut (Beaty, 2013) perilaku sosial adalah perilaku yang mencerminkan kepedulian atau perhatian dari seseorang anak ke anak lainnya, misalnya dengan membantu, menghibur, atau hanya tersenyum pada anak lain. Kajian saat ini menemukan bahwa perilaku peduli seperti ini sebagai respons terhadap pertumbuhan emosional orang lain yang diprediksikan oleh kualitas hubungan antara guru dan anak atau dengan teman sebayanya.

Menurut (Sofyan, 2014) perkembangan sosial merupakan memperoleh kemampuan berperilaku yang sesuai dengan tuntutan sosial dan mampu bersosialisasi dengan memerlukan tiga proses sebagai berikut dengan baik, anak-anak harus menyukai orang dan aktivitas sosial, jika mereka berhasil melakukan mereka akan dapat menyesuaikan diri dengan baik dan akan diterima sebagai anggota kelompok.

Kemampuan bersosialisasi atau disebut juga sebagai kecerdasan interpersonal menurut (Lwin, 2008) adalah "Kemampuan untuk berhubungan dengan orang-orang di sekitar kita". Kecerdasan ini adalah kemampuan untuk memahami dan memperkirakan perasaan, temperamen, suasana hati, maksud dan keinginan orang lain dan menanggapinya secara layak. Kecerdasan inilah yang memungkinkan kita untuk membangun hubungan dengan masyarakat. Kecerdasan interpersonal harus dibina selama tahap pendewasaan. kecerdasan interpersonal bukan sesuatu yang dilahirkan bersama anak tetapi sesuatu yang harus dikembangkan melalui pembinaan dan pengajaran seperti kecerdasan lainnya.

Menurut (Hurlock E dalam Hasnida, 2014) perkembangan sosial berarti perolehan kemampuan berperilaku yang sesuai dengan tuntutan sosial dan memerlukan tiga proses yaitu :

a) Belajar berperilaku yang dapat diterima secara sosial

b) Memainkan peran sosial yang dapat di terima

c) Perkembangan sikap sosial

Kemampuan bersosialisasi merupakan cara anak dalam melakukan interaksi baik dalam hal bertingkah laku maupun dalam hal berkomunikasi dengan orang lain. Kebanyakan anak merasa kesulitan dalam berinteraksi dengan teman, guru maupun orang yang baru dikenalnya. Anak akan baik perkembangan keterampilan sosialnya apabila pola asuhnya baik pula yang diberikan oleh orangtuanya.Kemampuan 
bersosialiasi juga diartikan mampu menyesuaikan diri dengan tuntutan yang ada dilingkungannya agar terhindar dari berbagai masalah dalam berinteraksi dengan temannya, serta mampu menghindari konflik dengan sesamanya saat berkomunikasi secara fisik(tatap muka) ataupun secara verbal(bahasa).Berkat kemampuan bersosialisasi anak dapat menyesuaikan dirinya dengan kelompok teman sebaya maupun dengan lingkungan masyarakat sekitar.

Perilaku sosial merupakan hal yang penting untuk anak, anak mampu menerima sudut pandang orang lain, anak memiliki sikap empati atau kepekaan terhadap perasaan orang lain, anak mampu mendengarkan orang lain, anak memiliki kemampuan untuk memulai hubungan dengan orang lain, anak dapat menyelesaikan konflik dengan orang lain, anak memilik kemampuan berkomunikasi dengan orang lain, anak memiliki sikap bersahabat atau mudah bergaul dengan teman sebayanya, anak memiliki sikap tenggang rasa dan perhatian terhadap orang lain, anak dapat memperhatikan kepentingan sosial seperti tolong menolong.

Tindakan yang bertujuan untuk menolong orang lain tanpa imbalan mengajarkan kepada anak-anak untuk belajar ikhlas membantu dengan sesuka hati, tidakan suka rela pun perbuatan yang baik untuk mengajarkan kepada anak-anak jika ingin menolong orang lain harus sesuka hati, dan tindakan yang menghasilkan sesuatu yang baik orang tua harus berpeilaku baik kepada orang lain agar anak melihat kebaikan orang tua dan anak akan mengikuti meniru perilaku orang tua, ajarakan anak-anak hal yang baik dan beri contoh sesuatu yang baik kepada anak.

Dalam (Trianto, 2011) pemodelan merupakan konsep dasar dari teori belajar sosial yang dikembangkan oleh Albert Bandura. Menurut Bandura sebagian besar manusia belajar melalui pengamatan secara selektif dan mengingat tingkah lakuh orang lain. Seseorang belajar menurut teori ini dilakukan dengan mengamati tingkah laku orang lain (model), hasil pengamatan itu kemudian dimantapkan dengan cara menghubungkan pengalaman baru dengan pengalaman sebelumnya atau mengulangulang kembali. Dengan jalan ini memberi kesempatan kepada orang tersebut untuk mengekspresikan tingkah laku yang dipelajarinya.

Menurut penelitian teori Bandura ini yaitu pengamatan tentang tingkah laku anak dan apa saja yang di lakukan anak pada saat anak bermain. Karena teori ini dilakukan dengan mengamati tingkah laku orang lain (medel) maksudnya disini yaitu anak belajar dengan melihat tingkah laku seseorang apapun yang di kerjakan orang dewasa (orang tua) maka itu akan menjadi contoh bagi anaknya.

Menurut kementrian pendidikan Nasional (2015) tentang peraturan mentri pendidikan dan kebudayaan republik Indonesia nomor 137 tahun 2013 indikator tingkat pencapaian perkembangan anak usia 5-6 tahun adalah sebagai berikut:

Tabel 1.1 Indikator Perkembangan Sosial Anak Usia Dini

\begin{tabular}{|l|l|l|}
\hline No & \multicolumn{3}{|c|}{ Indikator Perkembangan Sosial Anak Usia Dini } \\
\hline 1. & Lingkup perkebangan & \multicolumn{1}{|c|}{$\begin{array}{l}\text { Indikator Tingkat Pencapaian } \\
\text { Perkembangan Anak Usia 5-6 Tahun }\end{array}$} \\
\hline 2. & $\begin{array}{l}\text { Sosial } \\
\text { Kesadaran diri }\end{array}$ & $\begin{array}{l}\text { 1.Memperlihatkan kemampuan diri untuk } \\
\text { menyesuaikan dengan situasi } \\
\text { 2.Mengenal perasaan sendiri dan mengelolanya secara } \\
\text { wajar (mengendalikan diri secara wajar) }\end{array}$ \\
\hline
\end{tabular}




\begin{tabular}{|l|l|l|}
\hline 3. & $\begin{array}{l}\text { Rasa tanggung jawab } \\
\text { untuk diri sendiri dan } \\
\text { orang lain }\end{array}$ & $\begin{array}{l}\text { 1.Mentaati aturan kelas (kegiatan,aturan) } \\
\text { 2.Bertanggung jawab atas perilakunya untuk kebaikan } \\
\text { diri sendiri dan orang lain }\end{array}$ \\
\hline 4. & Perilaku Prososial & $\begin{array}{l}\text { 1.Bermain dengan teman sebaya } \\
\text { 2.Mengetahui perasaan temannya dan merespon } \\
\end{array}$ \\
& & $\begin{array}{l}\text { secara wajar } \\
\text { 3.Menghargai hak/ karya orang lain } \\
\end{array}$ \\
& & 4.Bersikap kooperatif dengan teman \\
\hline
\end{tabular}

Faktor yang Mempengaruhi Perkembangan Sosial Anak Anak dilahirkan belum bersifat sosial, artinya anak tersebut belum memiliki kemampuan untuk bergaul dengan orang lain. Untuk mencapai kematangan sosial, anak harus belajar cara menyesuaikan diri dengan orang lain. Kemampuan ini diperoleh anak melalui berbagai kesempatan atau pengalaman bergaul dengan orang-orang di lingkungannya, baik orang tua, saudara, teman sebaya atau orang dewasa lainnya.

Menurut (Hurlock, 2000) perkembangan sosial anak dipengaruhi oleh dua hal yaitu pertama, lingkungan keluarga dan kedua, lingkungan di luar rumah.

a. Keluarga: Keluarga merupakan lingkungan pertama dan utama yang memberikan pengaruh terhadap berbagai aspek perkembangan anak, termasuk perkembangan sosialnya. Perkembangan sosial anak sangat dipengaruhi oleh proses perlakuan atau bimbingan orang tua dalam mengenalkan berbagai aspek kehidupan sosial, atau normanorma kehidupan bermasyarakat atau mendorong dan memberikan contoh kepada anaknya bagaimana menerapakan norma-norma tersebut dalam kehidupan sehari-hari

b. Lingkungan di luar rumah (Hurlock, 2000) mengatakan bahwa pengalaman sosial awal di lingkungan luar keluarga melengkapi pengalaman di lingkungan keluarga. Sekolah merupakan salah satu lingkungan di luar keluarga yang mempengaruhi ber- kembangnya sikap sosial anak. Menurut pendapat (sunarto dan Agung Hartono, 2002) pendidikan di sekolah merupakan proses sosialisasi anak yang terarah. Penanaman norma perilaku yang benar secara sengaja diberikan kepada peserta didik yang belajar di lembanga pendidikan (sekolah). Proses pengoperasian ilmu yang normatif dalam pendidikan, akan memberikan warna kehidupan sosial anak di dalam masyarakat dan kehidupan mereka yang akan datang. Guru akan mulai memasukkan pengaruh terhadap sosialisasi anak. Kepada peserta didik, akan dikenalkan norma-norma lingkungan dekat, dikenalkan pula norma-norma kehidupan bermasyarakat. Upaya yang dapat dilakukan oleh guru untuk mengembangkan aspek sosial anak usia dini.

Adapun Ciri-ciri Perkembangan Sosial Anak Usia Dini (Sujiono, 2009)Usia 5-6 tahun

a. Menyatakan gagasan yang kaku peran jenis kelamin

b. Memiliki teman baik, meskipun untuk jangka waktu yang pendek

c. Sering bertengkar tetapi dalam waktu yang singkat

d. Dapat berbagi dan mengambil giliran

e. Ikut ambil bagian dalam setiap kegiatan pengalaman di sekolah

f. Mempertimbangkan setiap guru merupakan hal yang sangat penting

g. Ingin menjadi yang nomor satu

h. Menjadi lebih posesif terhadap barang-barang kepunyaannya.

Faktor-Faktor yang Mempengaruhi Perkembangan Sosial AUD (Hurlock, 1995)

a. Faktor Lingkungan Keluarga 
Untuk mencapai kematangan sosial, anak harus belajar tentang cara-cara menyesuaikan diri dengan orang lain. Kemampuan ini diperoleh anak melalui kesempatan atau pengalaman bergaul dengan orang-orang dilingkungannya, baik orang tua, saudara, teman sebaya ataupun orang dewasa lainnya. Dan lingkungan keluarga adalah lingkungan yang pertama yang pertama akan dikenal anak.

Perkembangan anak sangat dipengaruhi oleh proses perlakuan atau bimbingan orang tua terhadap anak dalam mengenal berbagai aspek kehidupan sosial, atau norma-norma kehidupan bermasyarakat serta mendorong dan memberikan contoh kepada anaknya bagaimana menerapkan norma-norma tersebut dalam kehidupan sehari-hari. Proses bimbingan orang tua ini lazim disebut sosialisasi.

b. Faktor dari Luar Rumah

Faktor di luar rumah adalah wadah bagi anak untuk bersosialisasi. Di luar rumah anak akan bertemu dengan orang yang lebih banyak, seperti teman sebaya, orang yang lebih kecil darinya, orang dewasa, sehinggga sosialnya akan berjalan sesuai dengan perannya di lingkungan tersebut.

c. Faktor Pengaruh Pengalaman Sosial Anak

Jika seorang anak memiliki pengalaman sosial yang buruk, seperti tidak diperbolehkan main keluar rumah oleh orang tuanya, maka hal itu, akan berpengaruh bagi proses sosialisasinya kepada lingkungan sekitarnya yang berada di luar rumah. Hal ini, akan menyebabkan anak menjadi tidak tahu dan kurang bersosialisasi dengan lingkungan di luar rumah.

\section{Hasil Penelitian yang Relevan}

Beberapa penilitian yang relefan dengan penelitian ini adalah:

1. Penelitian yang dilakukan oleh Niken Farida yang berjudul "Pengaruh Penggunaan Metode Proyek Terhadap Perkembangan Sosoal Anak Usia 5-6 Tahun Di TK Salsa Percut Sei Tuan T. A 2015/2016 Berdasarkan hasil penilitian yang telah dilakukan maka dapat diambil kesimpulan bahwa: 1) Metode proyek adalah sebuah metode yang membutuhkan keaktifan dan kerjasama anak dengan memberikan kesempatan berupa pemberian sebuah kegiatan yang di kerjakan secara kelompok untuk mencapai tujuan bersama sehingga anak akan berusaha berinteraksi, bekerjasama, dengan temannya agar dapat menyelesaikan kegiatan.

2. Penilitian yang relevan dilakukan oleh Isti Sulistyowati yang berjudul " Penerapan metode pembelajaran proyek untuk meningkatkan kemampuan kerjasama anak usia 5-6 tahun di Tk Pertiwi XVII Kecematan Jatisrono Kabupaten Wonogiri”, Hasil penilitian ini menunjukan bahwa menggunakan metode proyek ini dapat meningkatkan kemampuan kerjasama anak.

Persamaan peniltian terdahulu dengan yang saya teliti adalah terletak pada model yang diterapkan sama-sama melibatkan anak-anak untuk lebih berperan dalam pebelajaran. Perbedaan yaitu peniliti yang dilakukan sebelumnya untuk meningkatkan kemampuan kerja sama, sedangkan peniliti sendiri ingin meningkatkan aspek pengembangan sosial anak.

\section{Metodologi Penelitian}

Jenis penelelittian ini adalah studi pustaka (Library Research). Study pustaka yang dimaksud dalam penelitian ini yaitu: penelitian yang pengumpulan datanya dilakukan di lapangan (perpustakaan) dan menggali sumber data bukan dari manusia. Sehingga dalam melakukan penelitian ini didasarkan atas pembacaan terhadap beberapa literatur yang memiliki informasi dan memiliki relevansi dengan topik penelitian. Metode pengumpulan data menggunakan berbagai literatur yang berkaitan dengan penelitian ini. Adapun sumber data dalam penelitian ini berupa jurnal, laporan hasil penelitian,buku, hasil seminar. yang memiliki relevansi dengan topik penelitian. Objek dalam penelitian ini yaitu berkaitan 
dengan variabel perkembangan sosial anak usia dini dan berkaitan dengan variabel metode proyek.

\section{E. Kesimpulan}

Perkembangan sosial merupakan pencapaian kematangan dalam hubungan sosial. Dapat juga diartikan sebagai proses belajar untuk menyesuaikan diri terhadap norma-norma kelompok, moral, dan tradisi; meleburkn diri menjadi suatu kesatuan yang saling berkmunikasi dan berkerja sama dengan orang banyak. Sehingga anak menjadi anak extrovert atau anak cukup antusias dalam hal-hal baru dan senang bergaul. anak yang ramah dalam bersosialisasi dimana anak untuk mengambil keputusan atas kebersamaan kesepakatan bersama inilah yang diharapkan oleh bangsa dan Negara. Disisi lain anak introvert artinya anak tidak mau bersoaialisasi dan mengambil keputusan atas dirinya tanpa memperhatian teman yang lain. Oleh karena itu, kita sebagai pendidik anak usia dini seyogianya membimbing, membina dan melatih anak bersosialisasi untuk menjadi orang yang matang bersosial kelak dewasa menjadi keadilan sosial di masyarakat sesuai dengan sila kelima dari Pancasila.

Jadi metode proyek merupakan sala satuh cara untuk memecahkan masaalah terkait perkembangan sosial anak keunggulan metode proyek ini diantranya anak terlibat dalam suatu kegiatan bersama yang memacu anak untuk berinteraksi dengan temanya sehingga berpengaruh terhadap perkembangan sosialnya penggunaan metode proyek ini dapat membiasakan anak berinteraksi dengan sesamanya. Oleh sebab itu penggunaan metode proyek diharapkan dapat meningkatkan perkembangan sosial anak. 


\section{DAFTAR PUSTAKA}

Agustiana, Rima. 2017. Meningkatkan Perkembangan Sosial Anak Usia Dini Melalui Metode Proyek Pada Anak Kelompok B Di TK Sayang Bunda Kelurahan Pijoan. Jurnal di akses pada tgl 9/05/2020

Alfiana, Tutik. 2015. Penerapan Metode Proyek Untuk Meningkatkan Ketrampilan Sosial Anak dalam Bekerjasama Pada Anak Didik Kelompok B2di TK Kreatif Zaid Bin Tsabit Kecamatan Nglegok Kabupaten Blitar.

Beaty, Janice J. 2013.Observasi perkembangan anak usia dini, Jakarta: Kencana prenadamedia group. (Edisi ketujuh).

Djamarah, dan Azwan Z,. (2014).Strategi Belajar Mengajar. Jakarta : PT. Rineka Cipta.

Hurlock, Elizabeth B. 1978. Child Development (terj. Med Meitasari Tjandrasa). New York: Mc Graw Hill.

Hasnida, 2014, Analisis Kebutuhan Anak Usia Dini, Jakarta : PT, Luxima Metro Media.

Hurlock, E.B. (1978a),Perkembangan Anak.,Jakarta.Erlangga.

Kementrian pendidikan dan kebudayaan,. 2015,Pedoman Pengelolaan Pembelajaran Pendidikan AnakUsia Dini, Jakarta Derektorat Pembinaan Pendidikan Anak Usia Dini.

Lwin, dkk (2008), Cara Mengembangkan Berbagai Komponen Kecerdasan, Jakarta:Indeks.

Masitoh, dkk. (2005). Pendekatan Belajar Aktif di Taman Kanak-kanak. Jakarta: Depdiknas.

Moeslichatoen. (2004). Metode Pengajaran Di Taman Kanak-Kanak. Jakarta: PT.Rineka Cipta.

Rooprine, J \& Jhonson, J. 2011, Pendidikan Anak Usia Dini Dalam Berbagai Pendekatan, Jakarta Kencana.

Roopnarine dan Johnshon. 2011,Pendidikan Anak Usia Dini Dalam Berbagai Pendekatan, Jakarta: Kencana Prenada Media Grup.

Sugiyono, (2015:15), Metode penelitian kuantitatif dan kualitatif, Alfabeta Bandung.

Sujiono Yuliani Nurani, 2009. Konsep Dasar Pendidikan Anak Usia Dini,Jakarta: PT Indeks.

Sunaryo. (2014:42), Biopsikologi: Pembelajaran Perilaku,Bandung: Alfabeta.

Sofyan, Hendra. 2014, Perkembangan Anak Usia Dini dan Cara Praktis Peningkatannya, Jakarta : CV,Infomedika,

Susanto, Ahmad, 2014, Perkembangan Anak Usia Dini, Jakarta: Prenadamedia Group.

Tim Preschool Online, 2015, Serunya Dunia Anak Usia Dini, Panda Media, Jakarta.

Trianto. 2011. Model Pembelajaran Terpadu. Jakarta: Bumi Aksara.

Yus, Anita. Dr.2011 Penilaian Perkembangan Belajara Anak Taman Kanak Kanak. Jakarta: Kencana Prenada. 
Yusuf, Syamsu. (2006). Psikologi Perkembangan Anak dan Remaja. Bandung: PT. Remaja Rosdakarya. 